University of Nebraska - Lincoln

DigitalCommons@University of Nebraska - Lincoln

\title{
Effects of Solids Removal on Water Quality and Channel Catfish Production in a Biofloc Technology Production System
}

\author{
Bartholomew W. Green \\ USDA, Agricultural Research Service, bart.green@usda.gov \\ Kevin K. Schrader \\ USDA, Agricultural Research Service, kevin.schrader@usda.gov \\ Matthew McEntire \\ USDA, Agricultural Research Service, matthew.mcentire@usda.gov
}

Follow this and additional works at: https://digitalcommons.unl.edu/usdaarsfacpub

Part of the Agriculture Commons, and the Aquaculture and Fisheries Commons

Green, Bartholomew W.; Schrader, Kevin K.; and McEntire, Matthew, "Effects of Solids Removal on Water Quality and Channel Catfish Production in a Biofloc Technology Production System" (2019). Publications from USDA-ARS / UNL Faculty. 2415.

https://digitalcommons.unl.edu/usdaarsfacpub/2415

This Article is brought to you for free and open access by the U.S. Department of Agriculture: Agricultural Research Service, Lincoln, Nebraska at DigitalCommons@University of Nebraska - Lincoln. It has been accepted for inclusion in Publications from USDA-ARS / UNL Faculty by an authorized administrator of DigitalCommons@University of Nebraska - Lincoln. 


\title{
Effects of solids removal on water quality and channel catfish production in a biofloc technology production system
}

\author{
Bartholomew W. Green (1) ${ }^{a}$, Kevin K. Schrader ${ }^{b}$, and Matthew McEntire ${ }^{a}$ \\ aUnited States Department of Agriculture (USDA), Agricultural Research Service (ARS)—Harry K. \\ Dupree Stuttgart National Aquaculture Research Center, Stuttgart, Arkansas, USA; bUnited States \\ Department of Agriculture, Agricultural Research Service, Natural Products Utilization Research Unit, \\ National Center for Natural Products Research, University, Mississippi, USA
}

\begin{abstract}
Total suspended solids control was evaluated in a channel catfish (Ictalurus punctatus) biofloc technology production system. Settling chamber flow rates were $0.9(\mathrm{LO})$ or $2.9(\mathrm{HI}) \mathrm{L} / \mathrm{min}$ to reduce total suspended solids to $300 \mathrm{mg} / \mathrm{L}$; solids were not removed from control tanks. Channel catfish yields $\left(7.6-8.7 \mathrm{~kg} / \mathrm{m}^{3}\right)$ were not affected significantly, but control fish were skewed toward smaller size classes. Control treatment channel catfish tolerated $1,410 \mathrm{mg} / \mathrm{L}$ total suspended solids without adverse effects. LO- and HI-treatment fillet geosmin concentrations were high enough to be designated as off-flavor. Water quality results suggested that nitrification was affected by solids removal.
\end{abstract}

\section{KEYWORDS}

Biofloc technology; channel catfish; total suspended solids; geosmin; MIB

\section{Introduction}

High daily feeding rate in response to high stocking rate is one characteristic of the biofloc technology (BFT) production system. In the BFT system, mean daily feed rate ranges from 78 to $88 \mathrm{~g} / \mathrm{m}^{3}$ for white shrimp (Litopenaeus vannamei) (Gaona et al. 2017; Ray, Dillon, and Lotz 2011; Ray et al. 2010; Schveitzer et al. 2013), from 58 to $88 \mathrm{~g} / \mathrm{m}^{3}$ for channel catfish (Ictalurus punctatus) (Green and Schrader 2015; Green, Schrader, and Perschbacher 2014; Schrader, Green, and Perschbacher 2011), and from 150 to $250 \mathrm{~g} / \mathrm{m}^{3}$ for tilapia (Oreochromis spp.) (Azim and Little 2008; Milstein et al. 2001). In contrast, mean daily feeding rate in intensively managed earthen ponds rarely exceeds $100 \mathrm{~kg} / \mathrm{ha}$ (approximately $7-11 \mathrm{~g} / \mathrm{m}^{3}$ depending upon mean pond depth). Concomitant with the high feeding rate is an increase in total suspended solids (TSS) in the BFT system. In the absence of solids removal, TSS and feed input, nitratenitrogen, or soluble reactive phosphorus are positively correlated (Green and Schrader 2015; Green, Schrader, and Perschbacher 2014). While 
removing solids from a shrimp BFT system affected significantly concentrations of water quality variables (Ray, Dillon, and Lotz 2011; Ray et al. 2010), the effect of solids removal on water quality in a catfish BFT system remains to be investigated.

Increased TSS concentration can be detrimental to culture animal performance. Weekly means of daily feed consumption by channel catfish being grown to stocker size in an outdoor BFT system ceased to increase once TSS concentration exceeded 560-850 mg/L (Green, Schrader, and Perschbacher 2014). These authors reported some mortality and abnormal swimming behavior once TSS exceeded 2,000 mg/L. Reducing TSS to $300 \mathrm{mg} / \mathrm{L}$ or less using settling chambers to remove solids improves shrimp growth and yield (Gaona et al. 2017; Ray, Dillon, and Lotz 2011; Ray et al. 2010; Schveitzer et al. 2013; Vinatea et al. 2010). Use of settling chambers in the channel catfish BFT system has not been tested but is warranted given the reduced feed consumption (and presumably, reduced growth) observed at high TSS concentrations (Green, Schrader, and Perschbacher 2014).

The microbial off-flavor compounds geosmin and 2-methylisoborneol (MIB) can accumulate in fish flesh and impart "earthy" and "musty" offflavors respectively. Episodes of earthy and musty off-flavors can render fish unmarketable and has been estimated to cost U.S. catfish producers \$10-60 million annually (Tucker 2000). Geosmin and MIB have been detected in the fillets of channel catfish reared in the outdoor BFT system without solids control, but the episodes and intensities of geosmin- and MIB-induced off-flavors are substantially lower compared to catfish grown in earthen ponds (Green and Schrader 2015; Green, Schrader, and Perschbacher 2014; Schrader, Green, and Perschbacher 2011). Actinomycetes in the genera Norcardia and Streptomyces are present in the biosolids found in multiple components of freshwater RAS systems and are attributed as the main sources of geosmin and MIB (Guttman and van Rijn 2008; Schrader and Summerfelt 2010). Biofloc particles in the catfish BFT system may provide a good substrate for actinomycete colonization given the positive correlations detected between geosmin or MIB and TSS in tank water (Green, Schrader, and Perschbacher 2014). However, there are no data on the effects of solids removal on geosmin and MIB concentrations in fillets from catfish grown in the BFT system.

The objective of this study was to evaluate the effect of three solids management protocols in an outdoor photoautotrophic-chemoautotrophic (mixotrophic) BFT production system on channel catfish production, the incidence and intensity of geosmin and MIB off-flavor in catfish fillets, and on water quality. 


\section{Materials and methods}

This experiment to determine the effect of solids management was carried out in nine $15.7-\mathrm{m}^{3}$ wood-framed, high-density polyethylene-lined tanks (described in detail by Green, Schrader, and Perschbacher 2014) located outdoors at the United States Department of Agriculture (USDA), Agricultural Research Service (ARS), Harry K. Dupree Stuttgart National Aquaculture Research Center (SNARC), Stuttgart, Arkansas, USA. During the 1-16 October 2013 U.S. government shutdown (days 165 to 180), the one essential employee (McEntire) authorized to work cared for all fish at SNARC. For this experiment, he ensured fish well-being, fed fish, drained settling chambers every two days, and maintained tank water levels as needed. All other experiment activities were suspended.

Each tank was equipped with a 117-L (operating volume) conical bottom settling chamber. Water was moved from the tank to the settling chamber by airlift pump; air injection depth controlled the flow rate. Two flow rates $(0.9$ and $2.9 \mathrm{~L} / \mathrm{min}$; $\mathrm{LO}$ and $\mathrm{HI}$ respectively) were the treatments tested; hydraulic retention time was 11.8 and $3.7 \mathrm{~d}$ respectively for the tanks and 127 and $40 \mathrm{~min}$ respectively for the settling chambers. Solids were not removed from control tanks. Three tanks were assigned randomly to each treatment. Settling chamber operation began on study day 52, once TSS concentration approximated $400 \mathrm{mg} / \mathrm{L}$ (Green, Schrader, and Perschbacher 2014), and continued uninterrupted through the end of the experiment. Settled solids were drained from chambers on average every $3 \mathrm{~d}$, and the solids removed were quantified (as dry matter) based on sludge TSS. The mean quantity of sludge discarded from each chamber every 2 days during the government shutdown was assumed to be the mean quantity removed on days 154,158 , 161, and 185. Solids retention time (SRT; days) was calculated each time solids were discharged as: $\mathrm{SRT}=(\mathrm{V} * \mathrm{TSS}) / \mathrm{S}_{\mathrm{d}}$, where $\mathrm{V}=$ system volume $\left(\mathrm{m}^{3}\right)$, tank TSS $\left(\mathrm{g} / \mathrm{m}^{3}\right)$, and $\mathrm{S}_{\mathrm{d}}=$ solids discharged $(\mathrm{g} / \mathrm{d})$ (Tchobanoglous, Burton, and Stensel 2003).

Tanks were filled on 8 April 2013 with groundwater (total alkalinity $=226.4 \mathrm{mg} / \mathrm{L}$ as $\mathrm{CaCO}_{3}$ ) and $2.3 \mathrm{~m}^{3}$ of water from a SNARC pond containing an algal bloom to enhance the development of the algal bloom in order to help control ammonia levels initially. During the next $26 \mathrm{~d}$ each tank was dosed with a total of $0.5 \mathrm{~kg} 9-27-0\left(\mathrm{~N}_{-} \mathrm{P}_{2} \mathrm{O}_{5}-\mathrm{K}_{2} \mathrm{O}\right)$ and $0.4 \mathrm{~kg} \mathrm{46-0-0}$ fertilizer, and $4.5 \mathrm{~kg}$ dried molasses and beet pulp (Sweet45; Westway Feed Products, New Orleans, Louisiana, USA), and treated with $2.5 \mathrm{~kg} \mathrm{CaCl}_{2}$ to ensure chloride concentration exceeded $100 \mathrm{mg} / \mathrm{L}$. Feed-grade sodium bicarbonate (Church \& Dwight, Co., Princeton, New Jersey, USA) was added to each tank as needed to maintain $\mathrm{pH}$ and total alkalinity following Loyless and Malone (1997). Water (ca. $0.9 \mathrm{~m}^{3} / \mathrm{d}$ ) was added to each tank on 27 occasions to replace losses from evaporation and draining of the settling chamber. 
Channel catfish (2012 year class; $46.9 \pm 12.4 \mathrm{~g} /$ fish) were stocked into tanks on 19 April 2013 at $15.0 \mathrm{fish} / \mathrm{m}^{3}\left(0.74 \pm 0.03 \mathrm{~kg} / \mathrm{m}^{3}\right)$. Animal care and experimental protocol were approved by the SNARC Institutional Animal Care and Use Committee and conformed to ARS Policies and Procedures 130.4 and 635.1 .

Fish in each tank were fed as much $32 \%$ protein feed (Delta Western Feed Mill, Indianola, Mississippi USA) as they could consume in $10 \mathrm{~min}$ (apparent satiation) and the quantity recorded. On days 63,98 , and 127 at least $20 \%$ of each tank's fish population was captured by seine net and weighed in bulk as two to three lots of at least 20 fish each, and fish were returned alive to their tank. Fish were harvested from all tanks on days 209-210. At harvest, a minimum of 75 fish/tank were weighed individually (to the nearest $0.1 \mathrm{~g}$ ), and the remainder were counted and weighed in bulk (to the nearest $0.1 \mathrm{~kg}$ ). The total fish biomass harvested per tank was the gross fish yield (GFY, $\mathrm{kg} / \mathrm{m}^{3}$ ), and the net fish yield (NFY, $\mathrm{kg} / \mathrm{m}^{3}$ ) was calculated as the final fish biomass minus the initial fish biomass. Individually weighed fish were assigned to size classes- $\mathrm{kg} / \mathrm{fish}$ (size range): submarketable (<0.34 kg/fish), out-of-size ( 0.34 to $0.45 \mathrm{~kg} /$ fish), 0.45 ( 0.45 to $0.57 \mathrm{~kg} / \mathrm{fish}$ ), 0.57 ( 0.57 to $0.68 \mathrm{~kg} /$ fish), 0.68 (0.68 to $0.79 \mathrm{~kg} / \mathrm{fish}), 0.79$ ( 0.79 to $0.91 \mathrm{~kg} / \mathrm{fish}), 0.91$ (0.91 to $1.02 \mathrm{~kg} /$ fish), and 1.02 ( $\geq 1.02 \mathrm{~kg} /$ fish). Feed conversion ratio (FCR) was calculated for each tank as the total quantity of feed fed on a dry matter basis divided by the net (wet) weight of fish harvested.

Five catfish were selected at random from each tank at harvest, euthanized immediately by cranial percussion, and filleted. Catfish fillets (one fillet/fish) were placed in individual plastic bags, vacuum sealed, and immediately frozen until overnight shipment to the USDA-ARS Natural Products Utilization Research Unit, University, Mississippi, USA, for analysis of geosmin and MIB levels. Fish fillets were maintained frozen until processed according to Lloyd and Grimm (1999) to obtain microwave distillates that were analyzed using the procedures of Lloyd et al. (1998) and as modified by Schrader et al. (2003) to quantify geosmin and MIB by solid phase microextraction and gas chromatography-mass spectrometry. Catfish samples were collected only at the end of the study to permit bioaccumulation of geosmin and/or MIB throughout the grow-out period and to ensure that adequate fillet material was available for analysis (>20 g/fillet).

Water samples were collected from each tank between 0700 and $0800 \mathrm{~h}$ and analyzed beginning $2 \mathrm{~d}$ before stocking fish and continuing at weekly intervals through the end of the experiment. Total ammonia-nitrogen $\left(\mathrm{NH}_{4}-\mathrm{N}\right)$ was analyzed fluorometrically using the o-phthaldialdehyde method in a flow injection system (Genfa and Dasgupta 1989). Nitrite-nitrogen $\left(\mathrm{NO}_{2}-\mathrm{N}\right.$, diazotization), nitrate-nitrogen $\left(\mathrm{NO}_{3}-\mathrm{N}\right.$, cadmium reduction), and soluble reactive phosphorus (PO4-P; ascorbic acid method) were analyzed using flow injection analysis according to manufacturer instructions (FIAlab 2500; FIAlab Instruments, Bellevue, Washington, USA). Total alkalinity, settleable solids, 
total suspended solids (TSS), volatile suspended solids (VSS), and settleable solids (SS) were measured using the methods of Eaton et al. (2005). Chlorophyll $a$ was extracted in 2:1 chloroform:methanol from phytoplankton (for this study, "phytoplankton" includes planktonic algae and cyanobacteria as well as biofloc-associated algae) previously filtered from water samples by using a $0.45-\mu \mathrm{m}$ pore size glass fiber filter, and the chlorophyll $a$ concentration in the extract was determined by spectroscopy (Lloyd and Tucker 1988). Sample pH was measured electrometrically (Accumet AB15; Fisher Scientific, Waltham, Massachusetts, USA).

Accumulation of $\mathrm{NO}_{3}-\mathrm{N}$ was used as a proxy for the quantity of $\mathrm{NH}_{4}-\mathrm{N}$ oxidized per gram of TSS, an indicator of the solids-specific nitrification rate (SSNR; $\mathrm{g} \mathrm{NH}_{4}-\mathrm{N} / \mathrm{g}$ TSS/d), and was estimated weekly using the change in $\mathrm{NO}_{3}-\mathrm{N}$ concentration as follows: $\mathrm{SSNR}=\left(\left[\mathrm{NO}_{3}-\mathrm{N}_{T 2}-\mathrm{NO}_{3}-\mathrm{N}_{T 1}\right] /[\mathrm{T} 2-\mathrm{T} 1]\right) /$ TSS, where T1 and T2 denote times 1 and 2 respectively in days (Water Environment Federation 1996).

Settling chamber effluent returning to each tank was sampled for TSS weekly beginning day 75 and continuing at 7-14-d intervals. Tank water TSS was assumed to represent settling chamber influent. The percent reduction in TSS was calculated based on settling chamber influent and effluent TSS.

Dissolved oxygen (DO) concentration and water temperature in each tank were monitored continuously by a galvanic oxygen sensor (Type III, Oxyguard, Birkerød, Denmark) and a thermistor (Model 109, Campbell Scientific, Logan, Utah, USA) connected to a datalogger (Model CR206 or CR1000, Campbell Scientific, Logan, Utah, USA).

After confirming homogeneity of variance and normality, fish production and water quality data were analyzed by mixed model analysis of variance (ANOVA) using PROC MIXED and regression analysis (PROC REG) in SAS version 9.4 (SAS Institute, Inc., Cary, North Carolina, USA). Regression line slopes determined for each tank were compared using PROC MIXED. The CONTRAST statement was used to compare treatment means in PROC MIXED. Settling chamber flow rate was the fixed effect and tank the random effect for the MIXED procedure. Percent data were log transformed prior to data analysis (Sokal and Rohlf 1995). To determine if there were associations between treatment and fish in each market size category, market size distributions were analyzed by PROC FREQ in SAS version 9.4 to produce Chisquare and likelihood ratios. Water quality data were divided into two periods for statistical analyses: (1) presettling chamber operation (days 1 to 51 ) and (2) settling chamber operation (days 52 to harvest). The PROC CORR procedure was used to calculate Spearman correlation coefficients within treatment for weekly $\mathrm{NH}_{4}-\mathrm{N}$ and chlorophyll a concentrations and weekly averages of daily feed input. Differences among treatments were declared significant at $\mathrm{P} \leq 0.05$. 


\section{Results}

Daily feed consumption (as \% of biomass) in all treatments decreased linearly as individual weight increased, and regression line slopes did not differ significantly $(\mathrm{P}>0.05)$ among treatments. Daily feed consumption averaged $3.0 \%$ and $0.9 \%$ of biomass at the beginning and end of the experiment respectively. Sustained, high daily feed consumption (peak feed) occurred from day 51 to 148 , did not differ significantly among treatments $(\mathrm{P}=0.240)$, and averaged 99.3, 105.7, and $111.0 \mathrm{~g} / \mathrm{m}^{3}$ for the control, LO, and HI treatments respectively. Total feed consumption and FCR did not differ significantly among treatments (Table 1).

Mean individual fish weight at harvest ranged from 541.7 to $591.6 \mathrm{~g} / \mathrm{fish}$ and did not differ significantly among treatments $(P=0.384$; Table 1$)$. Fish growth during the experiment was linear in all treatments, and analysis of growth curve slopes (data not shown) did not reveal significant treatment differences $(\mathrm{P}=0.362)$.

Gross and net fish yields did not differ significantly among treatments (Table 1). Survival also did not differ significantly among treatments. An analysis of covariance, performed because LO treatment survival was 6.5\% lower than the remaining treatments, indicated survival was not a covariate $(\mathrm{P}=0.430)$. No significant treatment differences were detected for fillet geosmin $(\mathrm{P}=0.251)$ or MIB $(\mathrm{P}=0.329)$ concentrations (Table 1$)$.

Distributions of harvested fish size differed significantly among treatments (Figure 1; $\mathrm{P}<0.001$ ). The fish population in the control treatment was skewed toward the smaller size classes, and frequency analysis results indicated a greater than expected number of fish in the submarketable, out-of-size, and $0.45 \mathrm{~kg} /$ fish size classes, and fewer than expected numbers in each of the larger size classes. Numbers of fish in each size class in the LO treatment approximated the expected numbers for all size classes. In the HI treatment, there were

Table 1. Least squares mean gross fish yield (GFY), net fish yield (NFY), total feed fed, individual weight, survival, feed conversion ratio (FCR), fillet geosmin (GSM), and 2-methylisoborneol (MIB) concentrations for channel catfish reared for 210 days in a biofloc technology production system subjected to two levels of settling chamber influent flow rate: $\mathrm{LO}=0.9 \mathrm{~L} / \mathrm{min}, \mathrm{HI}=2.9 \mathrm{~L} / \mathrm{min}$. Solids were not removed from control tanks.

\begin{tabular}{|c|c|c|c|c|c|}
\hline \multirow[b]{2}{*}{ Variable } & \multicolumn{3}{|c|}{ Treatment } & \multicolumn{2}{|c|}{ Pooled } \\
\hline & Control & LO & $\mathrm{HI}$ & SE & $\operatorname{Pr}>F^{*}$ \\
\hline GFY $\left(\mathrm{kg} / \mathrm{m}^{3}\right)$ & 7.7 & 7.6 & 8.7 & 0.4 & 0.119 \\
\hline $\mathrm{NFY}\left(\mathrm{kg} / \mathrm{m}^{3}\right)$ & 6.9 & 6.9 & 8.0 & 0.4 & 0.124 \\
\hline Total Feed $\left(\mathrm{kg} / \mathrm{m}^{3}\right)$ & 13.7 & 14.4 & 15.4 & 0.5 & 0.147 \\
\hline Individual Weight (g/fish) & 541.7 & 579.5 & 591.6 & 24.5 & 0.384 \\
\hline Survival (\%) & 96.7 & 90.4 & 97.2 & 0.4 & 0.281 \\
\hline FCR & 1.7 & 1.6 & 1.6 & 0.1 & 0.443 \\
\hline Fillet GSM (ng/kg) & 13 & 2,151 & 1,288 & 812 & 0.251 \\
\hline Fillet MIB (ng/kg) & 19 & 50 & 32 & 13 & 0.329 \\
\hline
\end{tabular}

*Probability value for the $F$ statistic. 


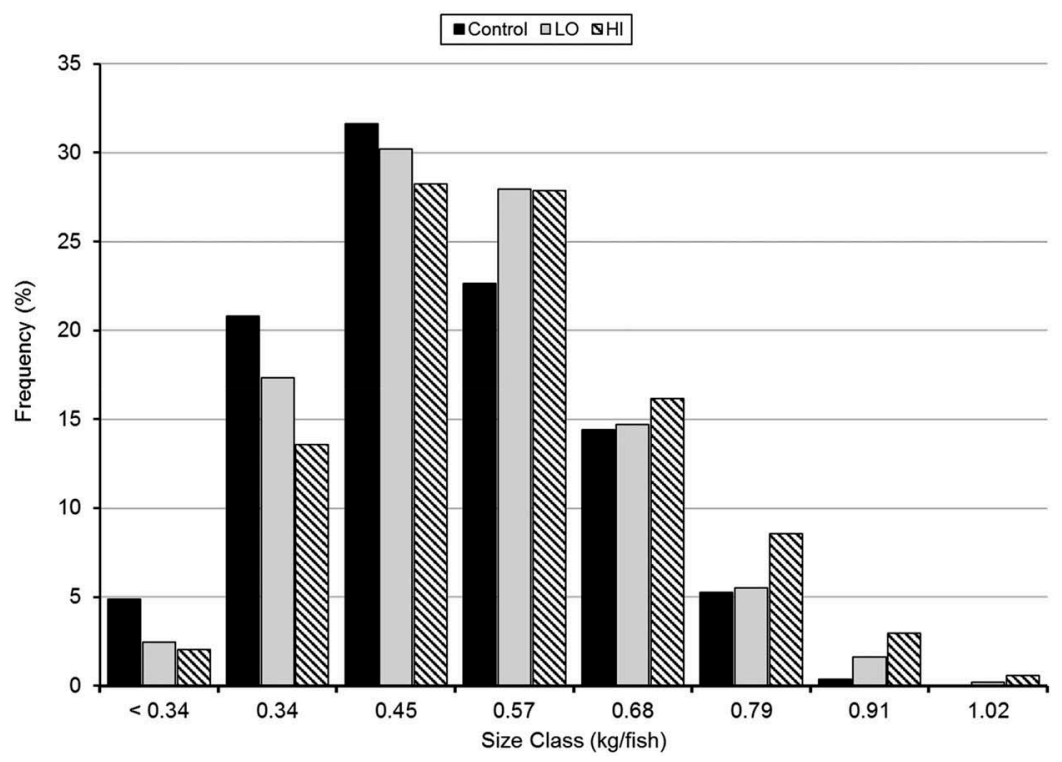

Figure 1. Size distribution of channel catfish harvested after 210 days from the biofloc technology production system control, LO, and HI treatments. Fish in the $<0.34$ and $0.34 \mathrm{~kg} /$ fish size classes are considered submarketable and out-of-size respectively. Settling chamber flow rates were $0.9 \mathrm{~L} / \mathrm{min}$ (LO) and $2.9 \mathrm{~L} / \mathrm{min}(\mathrm{HI})$. Solids were not removed from control tanks.

fewer than expected submarketable and out-of-size fish, expected numbers of fish in the $0.45,0.57$, and $0.68 \mathrm{~kg} /$ fish size classes, and greater than expected numbers in the larger size classes.

Minimum and mean DO were $68 \%$ and $87 \%$ of saturation $(5.2$ and $7.4 \mathrm{mg} / \mathrm{L}$ ) respectively and did not differ significantly $(\mathrm{P}=0.573)$ among treatments. Mean water temperature did not differ among treatments over the entire experiment $\left(\mathrm{P}=0.594 ; 24.4^{\circ} \mathrm{C}\right)$. No water quality treatment differences $(\mathrm{P}>0.05)$ were detected during period 1 (days 1-51). Significant treatment differences were detected in mean water quality variable concentrations during period 2 (Table 2). Control treatment means generally were significantly greater than one or both exchange treatments. However, no significant treatment differences were detected for $\mathrm{NH}_{4}-\mathrm{N}$, chlorophyll $a$, and $\mathrm{pH}$.

Mean chlorophyll $a$ concentration in all treatments peaked at 2,100 to $2,500 \mathrm{mg} / \mathrm{m}^{3}$ within the first month and by the end of the second month had declined and stabilized at 500 to $1,000 \mathrm{mg} / \mathrm{m}^{3}$ during period 2 (Figure 2, top). Increases in mean TSS concentration were similar among treatments during period 1, and TSS concentrations stabilized between $200-400 \mathrm{mg} / \mathrm{L}$ in the LO and $\mathrm{HI}$ treatments during period 2 but continued to accumulate in the control treatment (Figure 2, middle). Increase in mean $\mathrm{NO}_{3}-\mathrm{N}$ concentrations was similar among treatments until day 75, after which the curves diverged (Figure 2, bottom). 
Table 2. Water quality least squares means during periods 1 (stock to day 51 ) and 2 (day 52 to harvest). The channel catfish biofloc technology production system was subjected to two levels of settling chamber influent flow rate: $\mathrm{LO}=0.9 \mathrm{~L} / \mathrm{min}, \mathrm{HI}=2.9 \mathrm{~L} / \mathrm{min}$. Solids were not removed from control tanks.

\begin{tabular}{|c|c|c|c|c|c|c|c|c|c|c|}
\hline \multirow[b]{3}{*}{ Variable* } & \multicolumn{5}{|c|}{ Period 1} & \multicolumn{5}{|c|}{ Period 2} \\
\hline & \multicolumn{3}{|c|}{ Treatment } & \multirow[b]{2}{*}{ SE } & \multirow[b]{2}{*}{$\operatorname{Pr}>F$} & \multicolumn{3}{|c|}{ Treatment } & \multirow[b]{2}{*}{ SE } & \multirow[b]{2}{*}{$\operatorname{Pr}>F$} \\
\hline & Control & LO & $\mathrm{HI}$ & & & Control & LO & $\mathrm{HI}$ & & \\
\hline $\mathrm{NH}_{4}-\mathrm{N}$ & 0.38 & 0.29 & 0.41 & 0.09 & 0.612 & 0.03 & 0.05 & 0.05 & 0.01 & 0.104 \\
\hline $\mathrm{NO}_{2}-\mathrm{N}$ & 1.02 & 0.84 & 1.60 & 0.31 & 0.264 & $0.08 c$ & $0.18 \mathrm{~b}$ & $0.33 \mathrm{a}$ & 0.03 & 0.003 \\
\hline $\mathrm{NO}_{3}-\mathrm{N}$ & 6.19 & 6.29 & 7.21 & 0.58 & 0.441 & 85.9 a & $61.4 \mathrm{~b}$ & $73.4 \mathrm{ab}$ & 5.5 & 0.021 \\
\hline $\mathrm{PO}_{4}-\mathrm{P}$ & 1.28 & 1.48 & 1.75 & 0.14 & 0.140 & $24.8 \mathrm{a}$ & 14.7 b & $18.2 \mathrm{ab}$ & 1.9 & 0.029 \\
\hline Chl $a$ & 1,618 & 1,714 & 1,357 & 129 & 0.209 & 706 & 679 & 638 & 56 & 0.705 \\
\hline T Alk & 198.5 & 196.9 & 182.6 & 8.8 & 0.430 & $103.2 \mathrm{a}$ & $98.0 \mathrm{a}$ & $78.8 \mathrm{~b}$ & 3.6 & 0.007 \\
\hline $\mathrm{pH}$ & 8.49 & 8.48 & 8.36 & 0.05 & 0.281 & 7.51 & 7.68 & 7.52 & 0.04 & 0.054 \\
\hline SS & 14 & 14 & 16 & 2 & 0.719 & $65 a$ & $17 \mathrm{~b}$ & $14 \mathrm{~b}$ & 1 & $<0.001$ \\
\hline TSS & 242.8 & 247.5 & 259.3 & 12.8 & 0.661 & $829.4 \mathrm{a}$ & $306.3 \mathrm{~b}$ & $305.0 \mathrm{~b}$ & 29.3 & $<0.001$ \\
\hline VSS & 213.1 & 217.2 & 218.4 & 10.5 & 0.933 & $672.2 \mathrm{a}$ & $268.6 \mathrm{~b}$ & $263.1 \mathrm{~b}$ & 21.2 & $<0.001$ \\
\hline
\end{tabular}

*Total ammonia-nitrogen $\mathrm{mg} / \mathrm{L} \mathrm{NH}_{4}-\mathrm{N}$, nitrite-nitrogen $\mathrm{mg} / \mathrm{L} \mathrm{NO} \mathrm{N}_{2}-\mathrm{N}$, nitrate-nitrogen $\mathrm{mg} / \mathrm{L} \mathrm{NO}_{3}-\mathrm{N}$, soluble reactive phosphorus $\mathrm{mg} / \mathrm{L} \mathrm{PO}_{4}-\mathrm{P}$, chlorophyll $a(\mathrm{Chl} a) \mathrm{mg} / \mathrm{m}^{3}$, total alkalinity ( $\left.\mathrm{T} \mathrm{Alk}\right) \mathrm{mg} / \mathrm{L}$ as $\mathrm{CaCO}_{3}$, settleable solids (SS) $\mathrm{mL} / \mathrm{L}$, total suspended solids (TSS) $\mathrm{mg} / \mathrm{L}$, volatile suspended solids (VSS) $\mathrm{mg} / \mathrm{L}$.

Regression line slopes for $\mathrm{NO}_{3}-\mathrm{N}$ concentration over time during period 2 differed significantly among treatments. Control treatment mean slope $(0.842 \pm 0.069 ; \pm$ standard error, SE) was significantly greater $(\mathrm{P}<0.010)$ than for the LO treatment $(0.477 \pm 0.069)$ but not different $(\mathrm{P}=0.054)$ from the HI treatment $(0.608 \pm 0.069)$. And HI and LO treatment mean slopes did not differ significantly $(\mathrm{P}=0.226)$. The $\mathrm{HI}$ treatment mean slope was $28 \%$ smaller than the control and 22\% larger than the LO treatment means. Estimated solids-specific nitrification rate during period 2 did not differ significantly $(\mathrm{P}=0.180)$ among treatments and averaged 0.0012, 0.0012, and $0.0017 \mathrm{~g} \mathrm{NH}_{4}-\mathrm{N} / \mathrm{g} \mathrm{TSS} / \mathrm{d}$ for the control, LO, and HI treatment respectively.

Sodium bicarbonate additions to tanks varied throughout the experiment. Mean total sodium bicarbonate addition to control treatment tanks was $630 \mathrm{~g} / \mathrm{m}^{3}$, significantly greater than the $246 \mathrm{~g} / \mathrm{m}^{3}(\mathrm{P}=0.003)$ or $405 \mathrm{~g} / \mathrm{m}^{3}$ $(\mathrm{P}=0.031)$ added to LO or $\mathrm{HI}$ treatment tanks respectively. Additions did not differ significantly $(\mathrm{P}=0.096)$ between the LO and $\mathrm{HI}$ treatments. Total alkalinity did not differ significantly among treatments during period 1 but was significantly greater in the control and LO treatments during period 2 (Table 2).

Settling chambers reduced TSS on average by $80 \%$ and $63 \%(\mathrm{P}=0.050)$ for the LO and $\mathrm{HI}$ treatments respectively. On a dry matter basis solids removed as sludge from settling chambers averaged $36 \mathrm{~kg}$ and $39 \mathrm{~kg}(\mathrm{P}=0.221)$ for the $\mathrm{LO}$ and $\mathrm{HI}$ treatments respectively. The total volume of solids removed as sludge from settling chambers averaged 5,793 L and 5,464 L $(\mathrm{P}=0.173)$ for the LO and $\mathrm{HI}$ treatments respectively. The quantity of solids discharged as a percent of feed input did not differ significantly $(P=0.260)$ and averaged 

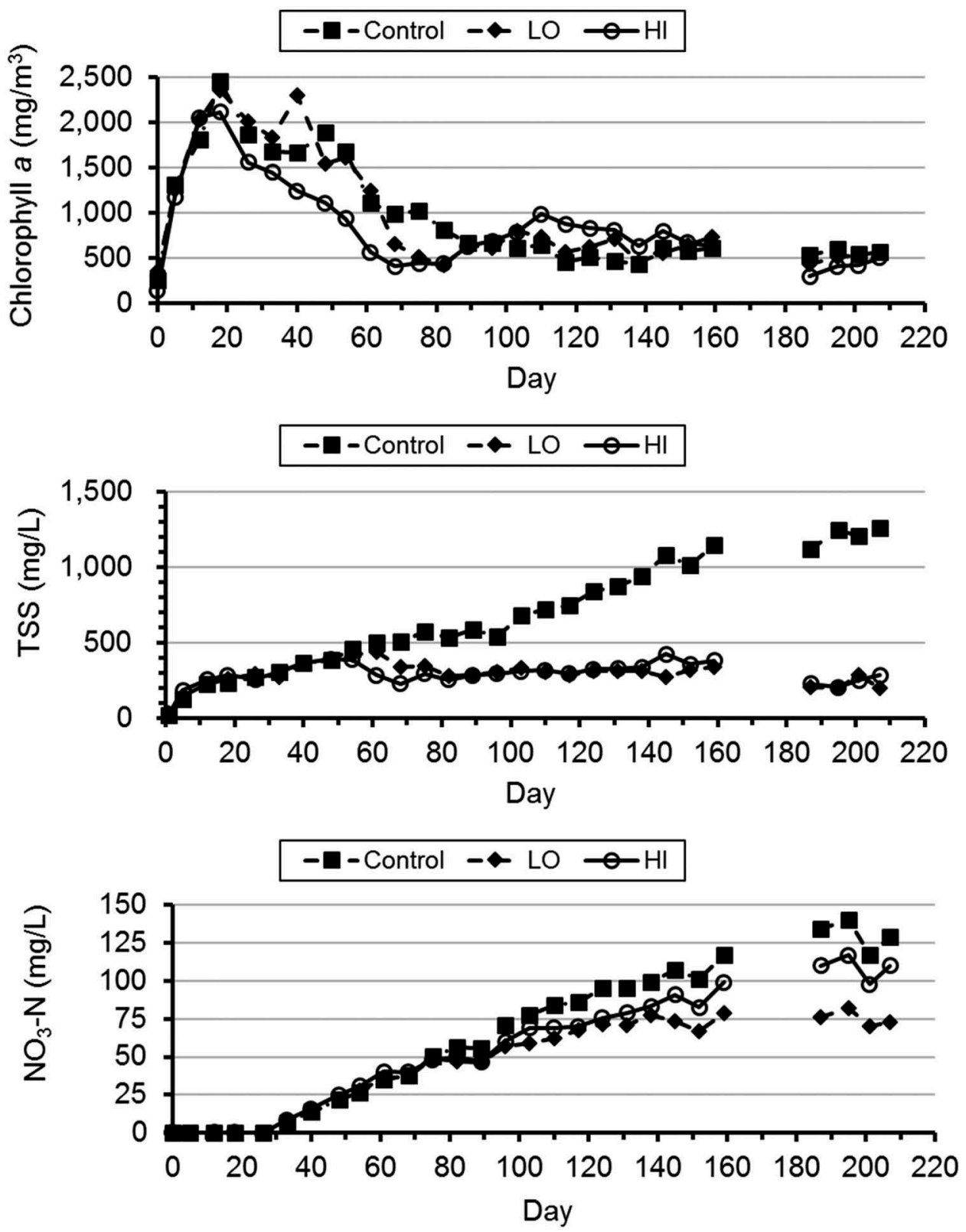

Figure 2. Mean weekly chlorophyll $a$ (top panel), total suspended solids (middle panel), and nitrate-nitrogen (bottom panel) concentrations in a channel catfish biofloc technology production system subjected to two levels of settling chamber influent flow rate: $L O=0.9 \mathrm{~L} / \mathrm{min}$, $\mathrm{HI}=2.9 \mathrm{~L} / \mathrm{min}$. Solids were not removed from control tanks. Settling chambers were activated on day 52. The gap in data corresponds to the 1-16 October 2013 shutdown of the USA government.

$15.6 \%$ and $16.1 \%$ for the LO and $\mathrm{HI}$ treatments respectively. Mean SRT was $11.0 \mathrm{~d}$ for the LO treatment, not significantly different $(\mathrm{P}=0.051)$ from the HI treatment $(8.4 \mathrm{~d})$. 


\section{Discussion}

When intensifying channel catfish production, biological processes occurring in the outdoor photoautotrophic-chemoautotrophic (mixotrophic) BFT system function to maintain water quality, primarily low $\mathrm{NH}_{4}-\mathrm{N}$ and $\mathrm{NO}_{2}-\mathrm{N}$ concentrations, in response to high feeding rates. Channel catfish likely derive minimal nutrition from the biofloc and provision of increasing quantities of formulated feed are necessary to sustain rapid growth (Bonneau et al. 1972; Lilyestrom, Romaire, and Aharon 1987). Metabolism of feed by fish drives the increase in solids (living and dead particulate organic matter) concentrations as noted in the control treatment and by Green, Schrader, and Perschbacher (2014). Unmanaged, TSS concentrations in an earlier BFT study increased to levels that appeared to impact channel catfish negatively, with unexplained mortality recorded at TSS $>2,000 \mathrm{mg} / \mathrm{L}$ and abnormal swimming behavior observed when TSS exceeded about 1,600 mg/L (Green, Schrader, and Perschbacher 2014). The absence of significant differences among treatments means in the present experiment for daily and total feed consumption, growth curve slopes, and production variables indicated that TSS concentration, which reached a maximum of 1,200 to $1,410 \mathrm{mg} / \mathrm{L}$ in control treatment tanks, did not affect fish adversely. Stocker-size catfish, which were grown by Green, Schrader, and Perschbacher (2014), may be more susceptible to high TSS concentrations than the food-size fish produced in this study.

Production variables were similar to results of previous experiments in the channel catfish BFT system (Green and Schrader 2015; Green, Schrader, and Perschbacher 2014; Schrader, Green, and Perschbacher 2011). Differential effects of TSS concentration on production variables are reported in other published studies. In a 21-d study, Poli, Schveitzer, and Nuñer (2015) reported that survival and mean final weight of larval South American catfish (Rhamdia quelen) reared for 21 days in BFT systems maintained at 157.0 to $908.7 \mathrm{mg} / \mathrm{L}$ TSS did not differ significantly. Shrimp growth in BFT culture was better when TSS concentration was low (less than about $300 \mathrm{mg} / \mathrm{L}$ ) (Gaona et al. 2017; Ray, Dillon, and Lotz 2011; Ray et al. 2010; Schveitzer et al. 2013; Vinatea et al. 2010), whereas survival was (Gaona et al. 2017; Schveitzer et al. 2013) or was not (Ray, Dillon, and Lotz 2011; Ray et al. 2010) affected by TSS concentration.

Despite the absence among treatments of significant differences in production variables, fish size distributions at harvest did vary significantly. Fish from the control treatment were skewed toward the smaller size classes, which can affect marketability (Wiese et al. 2006). Control treatment fish consumed $5 \%$ to $11 \%$ less feed than fish in the exchange treatments, which likely affected growth, and the cause of which is not known. Additional research on how TSS affects catfish gill morphology and hematology would 
be useful. Compared to the control treatment, GFY in the LO and HI treatments was $9 \%-12 \%$ higher for size classes $\geq 0.45 \mathrm{~kg} /$ fish and $23 \%-48 \%$ higher for size classes $\geq 0.57 \mathrm{~kg} /$ fish. Thus, more fish in the control treatment must be carried over to the next growing season, which increases risk to the farmer. While these differences were not significant, they will affect farm revenue.

Geosmin concentrations detected in fillet samples from the control treatment did not exceed previously reported threshold sensory detection limits of trained catfish processing plant flavor testers for geosmin (250-500 ng/kg), but did for the LO and HI treatments (Grimm, Lloyd, and Zimba 2004). The absence of a significant difference among treatments for fillet geosmin concentration resulted from the high among tank variability for the LO and HI treatments. Fillet concentrations of MIB did not exceed the 100-200 ng/kg sensory detection limit (Grimm, Lloyd, and Zimba 2004) in any treatment. Thus, fish from the LO and HI treatments likely would be classified as having an objectionable "earthy" off-flavor. The present results contrast with previous observations that in the outdoor BFT system the frequency and intensity of geosmin- and MIB-induced off-flavor in channel catfish is substantially lower than for earthen pond catfish culture (Green and Schrader 2015; Green, Schrader, and Perschbacher 2014; Schrader and Dennis 2005; Schrader, Green, and Perschbacher 2011). Off-flavor-producing cyanobacteria and actinomycetes are reported to occur episodically in the catfish BFT tanks, but their presence has not been correlated with high aqueous geosmin or MIB concentrations (Green, Schrader, and Perschbacher 2014; Schrader, Green, and Perschbacher 2011). However, the large variability of mean geosmin concentrations in the catfish flesh among the tanks within the solids removal treatments in the present study likely resulted from the inconsistent presence and/or abundance of geosmin-producing microorganisms in the BFT tanks. Further research to identify the source(s) of geosmin and MIB in the outdoor BFT system is needed.

Solids concentrations were reduced to around $300 \mathrm{mg} / \mathrm{L}$ in both solids removal treatments. The significantly lower slope of $\mathrm{NO}_{3}-\mathrm{N}$ accumulation in the LO compared to control treatment during period 2 suggests that nitrification decreased because of solids removal. Metabolic output of $\mathrm{NH}_{4}-\mathrm{N}$ by fish in all treatments likely was similar during period 2 because of similar feed input. The significantly lower quantities of sodium bicarbonate required to maintain $\mathrm{pH}$ and alkalinity and the slower accumulation of $\mathrm{NO}_{3}-\mathrm{N}$ in the solids removal treatments support the decreased nitrification hypothesis. Additionally, sludge retention times in exchange treatments were within the typical SRT of 3 to $18 \mathrm{~d}$ recommended for complete nitrification (Tchobanoglous, Burton, and Stensel 2003). Others also report decreased nitrification in shrimp BFT systems in response to solids removal. Nitrification rate inferred from inhibited dark bottle respiration was significantly lower in the $200 \mathrm{mg} / \mathrm{L}$ TSS treatment compared to 
the 400-600 and 800-1,000 mg/L TSS treatments (Schveitzer et al. 2013). And reducing TSS concentration from 782 to $459 \mathrm{mg} / \mathrm{L}$ significantly reduced nitrification rate as indicated by significantly different slopes for $\mathrm{NO}_{3}-\mathrm{N}$ concentration over time (Ray et al. 2010). Nitrification occurred when TSS concentration was maintained at about $300 \mathrm{mg} / \mathrm{L}$ but was not detected at about $200 \mathrm{mg} / \mathrm{L}$ TSS (Ray et al. 2012).

On the other hand, the observed decreased nitrification could be the result of dilution caused by addition of replacement water following draining of settling chambers. But since similar volumes of solids were drained from LO and HI treatment settling chambers, there should be no differential response because of dilution. Similarly, there is a danger with excessive solids removal of washing out the nitrifying bacteria from the system, thereby reducing nitrification and allowing heterotrophs to proliferate (Ebeling, Timmons, and Bisogni 2006; U.S. EPA 1993).

The fate of unaccounted for excreted nitrogen $(\mathrm{N})$ and phosphorus $(\mathrm{P})$ in the solids removal treatments compared to the control is unclear given the absence of significant treatment differences for total feed fed, FCR, and production variables. Unlike earthen ponds where the accumulation of organic N (Gross, Boyd, and Wood 2000) and $\mathrm{PO}_{4}-\mathrm{P}$ adsorption (Masuda and Boyd 1994) occur in pond sediments, neither process occurs in outdoor, HDPE-lined BFT tanks because they do not contain soil and similar sediments. Similar chlorophyll $a$ concentrations among treatments in the present experiment indicated that differential $\mathrm{N}$ and $\mathrm{P}$ uptake by phytoplankton likely would not elucidate the fate of unaccounted $\mathrm{N}$ and P. Ammonianitrogen can be lost by volatilization, and 3.8\%, on average, of $\mathrm{NH}_{4}-\mathrm{N}$ concentration can be volatilized at $\mathrm{pH}>8.3$ (Gross, Boyd, and Wood 1999). However, $\mathrm{NH}_{4}-\mathrm{N}$ volatilization in the present experiment likely was minimal because of low $\mathrm{NH}_{4}-\mathrm{N}$ concentration and $\mathrm{pH}$ in the mid-7 range. Denitrification in earthen ponds occurs in the sediments and can account for $17.4 \%$ of $\mathrm{N}$ losses in channel catfish ponds (Gross, Boyd, and Wood 2000; Hargreaves 1998). Denitrification also is reported to occur in anaerobic microenvironments in the water column of earthen ponds (Avnimelech and Zohar 1986). While anaerobic microenvironments likely did not occur in the tank water column during the present experiment because of the continuous aeration, denitrification, which was not measured, possibly occurred in the settling chamber. Evidence of denitrification was detected for settling chambers used to manage TSS levels in a shrimp brackish water BFT system (Ray, Dillon, and Lotz 2011). Both denitrification and dissimilatory nitrate reduction to ammonium were detected in laboratory reactors that contained biofloc particles from a tilapia BFT system (Chutivisut, Pungrasmi, and Powtongsook 2014). Although not quantified in the present experiment, $\mathrm{N}$ and $\mathrm{P}$ are lost from the system when sludge is drained from settling chambers. Nitrogen discharged as sludge from a shrimp BFT system 
ranged from $28 \%$ to $46 \%$ of total nitrogen discharged from the system (Arantes et al. 2017). Clearly, development of $\mathrm{N}$ and $\mathrm{P}$ budgets for the outdoor, mixotrophic BFT system would elucidate the fate of added nutrients.

In summary, both settling chamber flow rates effectively maintained TSS concentrations around $300 \mathrm{mg} / \mathrm{L}$. Channel catfish performance was not affected when exposed to TSS concentration as high as $1,410 \mathrm{mg} / \mathrm{L}$ and exhibited no apparent adverse effects. But fish size distribution was skewed toward larger sizes when solids were removed. Water quality results suggested that nitrification was reduced in response to solids removal, especially in the LO treatment. Fish fillets from the solids removal treatments contained enough geosmin to likely be classified as having an objectionable "earthy" off-flavor. Research is needed to identify the microbial source of geosmin and MIB in the outdoor catfish BFT system before the development of mitigation strategies can commence. Additionally, it appears important to maintain a TSS concentration that ensures rapid nitrification while any TSS reduction is unlikely to significantly affect the intensity of episodes of microbial-related off-flavor.

\section{Acknowledgments}

We thank Greg O’Neal, Paxton Harper, William Schiederer, Dewayne Harries, and Phaedra Page for their technical assistance during this study. Mention of trade names or commercial products is solely for the purpose of providing specific information and does not imply recommendation or endorsement by the U.S. Department of Agriculture. USDA is an equal opportunity provider and employer.

\section{Disclosure statement}

No potential conflict of interest was reported by the authors.

\section{ORCID}

Bartholomew W. Green (ib) http://orcid.org/0000-0003-3772-9404

\section{References}

Arantes, R., R. Schveitzer, W. Q. Seiffert, K. R. Lapa, and L. Vinatea. 2017. Nutrient discharge, sludge quantity and characteristics in biofloc shrimp culture using two methods of carbohydrate fertilization. Aquacultural Engineering 76:1-8. doi:10.1016/j. aquaeng.2016.11.002. 
Avnimelech, Y., and G. Zohar. 1986. The effect of local anaerobic conditions on growth retardation in aquaculture systems. Aquaculture 58:167-74. doi:10.1016/0044-8486(86) 90082-7.

Azim, M. E., and D. C. Little. 2008. The biofloc technology (BFT) in indoor tanks: Water quality, biofloc composition, and growth and welfare of Nile tilapia (Oreochromis niloticus). Aquaculture 283:29-35. doi:10.1016/j.aquaculture.2008.06.036.

Bonneau, D. L., J. W. McGuire, O. W. Tiemeier, and C. W. Deyoe. 1972. Food habits and growth of channel catfish fry. Ictalurus Punctatus. Transactions of the American Fisheries Society 101:613-19. doi:10.1577/1548-8659(1972)101<613:FHAGOC>2.0.CO;2.

Chutivisut, P., W. Pungrasmi, and S. Powtongsook. 2014. Denitrification and dissimilatory nitrate reduction to ammonium (DNRA) activities in freshwater sludge and biofloc from Nile tilapia aquaculture systems. Journal of Water and Environment Technology 12:347-56. doi:10.2965/jwet.2014.347.

Eaton, A. D., L. S. Clesceri, E. W. Rice, and A. E. Greenberg. 2005. Standard methods for the examination of water and wastewater. 21st ed. Washington, DC: American Public Health Association.

Ebeling, J. M., M. B. Timmons, and J. J. Bisogni. 2006. Engineering analysis of the stoichiometry of photoautotrophic, autotrophis, and heterotrophic removal of ammonia-nitrogen in aquaculture systems. Aquacultural Engineering 257:346-58.

Gaona, C. A. P., M. Souza de Almeida, V. Viau, L. H. Poersch, and W. Wasielesky Jr. 2017. Effect of different total suspended solids levels on a Litopenaeus vannamei (Boone, 1931) BFT culture system during biofloc formation. Aquaculture Research 48:1070-79. doi:10.1111/are.12949.

Genfa, Z., and P. K. Dasgupta. 1989. Fluorometric measurement of aqueous ammonia ion in a flow injection system. Analytical Chemistry 61:408-12. doi:10.1021/ac00180a006.

Green, B. W., and K. K. Schrader. 2015. Effect of stocking large channel catfish in a biofloc technology production system on production and incidence of common microbial offflavor compounds. Journal of Aquaculture Research and Development 6:314. doi:10.4172/ 2155-9546.1000314.

Green, B. W., K. K. Schrader, and P. Perschbacher. 2014. Effect of stocking biomass on solids, phytoplankton communities, common off-flavors, and production parameters in channel catfish biofloc technology production system. Aquaculture Research 45:1442-58. doi:10.1111/are.12096.

Grimm, C. C., S. Lloyd, and P. V. Zimba. 2004. Instrumental versus sensory detection of offflavors in farm-raised channel catfish. Aquaculture 236:309-19. doi:10.1016/j. aquaculture.2004.02.020.

Gross, A., C. E. Boyd, and C. W. Wood. 1999. Ammonia volatilization from freshwater fish ponds. Journal of Environmental Quality 28:793-97. doi:10.2134/jeq1999.00472425002800030009x.

Gross, A., C. E. Boyd, and C. W. Wood. 2000. Nitrogen transformations and balance in channel catfish ponds. Aquacultural Engineering 24:1-14. doi:10.1016/S0144-8609(00) 00062-5.

Guttman, L., and J. van Rijn. 2008. Identification of conditions underlying production of geosmin and 2-methylisoborneol in a recirculating system. Aquaculture 279:85-91. doi:10.1016/j.aquaculture.2008.03.047.

Hargreaves, J. A. 1998. Nitrogen biogeochemistry of aquaculture ponds. Aquacultural Engineering 166:181-212.

Lilyestrom, C. G., R. P. Romaire, and P. Aharon. 1987. Diet and food assimilation by channel catfish and Malaysian prawns in polyculture as determined by stomach content analysis and stable carbon isotope ratios. Journal of the World Aquaculture Society 18:278-88. doi:10.1111/jwas.1987.18.issue-4. 
Lloyd, S. W., and C. C. Grimm. 1999. Analysis of 2-methylisoborneol and geosmin in catfish by microwave distillation-solid-phase microextraction. Journal Agricultural and Food Chemistry 47:164-69. doi:10.1021/jf980419x.

Lloyd, S. W., J. M. Lea, P. V. Zimba, and C. C. Grimm. 1998. Rapid analysis of geosmin and 2-methylisoborneol in water using solid phase micro extraction procedures. Water Research 32:2140-46. doi:10.1016/S0043-1354(97)00444-2.

Lloyd, S. W., and C. S. Tucker. 1988. Comparison of three solvent systems for extraction of chlorophyll a from fish pond phytoplankton communities. Journal of the World Aquaculture Society 19:36-40. doi:10.1111/jwas.1988.19.issue-2.

Loyless, J. C., and R. F. Malone. 1997. A sodium bicarbonate dosing methodology for $\mathrm{pH}$ management in freshwater-recirculating aquaculture systems. The Progressive FishCulturist 59:198-205. doi:10.1577/1548-8640(1997)059<0198:ASBDMF>2.3.CO;2.

Masuda, K., and C. E. Boyd. 1994. Phosphorus fractions in soil and water of aquaculture ponds built on clayey Ultisols at Auburn, Alabama. Journal of the World Aquaculture Society 25:379-95. doi:10.1111/jwas.1994.25.issue-3.

Milstein, A., Y. Avnimelech, M. Zoran, and D. Joseph. 2001. Growth performance of hybrid bass and hybrid tilapia in conventional and active suspension intensive ponds. Israeli Journal of Aquaculture-Bamidgeh 53:147-57.

Poli, M. A., R. Schveitzer, and A. P. de O. Nuñer. 2015. The use of biofloc technology in a South American catfish (Rhamdia quelen) hatchery: Effect of suspended solids on the performance of larvae. Aquacultural Engineering 66:17-21. doi:10.1016/j. aquaeng.2015.01.004.

Ray, A. J., K. M. Dillon, and J. M. Lotz. 2011. Water quality dynamics and shrimp (Litopenaeus vannamei) production in intensive, mesohaline culture systems with two levels of biofloc management. Aquacultural Engineering 45:127-36. doi:10.1016/j. aquaeng.2011.09.001.

Ray, A. J., B. L. Lewis, C. L. Browdy, and J. W. Leffler. 2010. Suspended solids removal to improve shrimp (Litopenaeus vannamei) production and an evaluation of a plant-based feed in minimal-exchange, superintensive culture systems. Aquaculture 299:89-98. doi:10.1016/j.aquaculture.2009.11.021.

Ray, A. J., G. Seaborn, L. Vinatea, C. L. Browdy, and J. W. Leffler. 2012. Effects of biofloc reduction on microbial dynamics in minimal-exchange, superintensive shrimp, Litopenaeus vannamei, culture systems. Journal of the World Aquaculture Society 43:790801. doi:10.1111/jwas.2012.43.issue-6.

Schrader, K. K., and M. E. Dennis. 2005. Cyanobacteria and earthy/musty compounds found in commercial catfish (Ictalurus punctatus) ponds in the Mississippi Delta and MississippiAlabama Blackland Prairie. Water Research 39:2807-14. doi:10.1016/j.watres.2005.04.044.

Schrader, K. K., B. W. Green, and P. W. Perschbacher. 2011. Development of phytoplankton communities and common off-flavors in a biofloc technology system used for the culture of channel catfish (Ictalurus punctatus). Aquacultural Engineering 45:118-26. doi:10.1016/j. aquaeng.2011.08.004.

Schrader, K. K., N. P. D. Nanayakkara, C. S. Tucker, A. M. Rimando, M. Ganzera, and B. T. Schaneberg. 2003. Novel derivatives of 9,10-anthraquinone are selective algicides against the musty-odor cyanobacterium. Oscillatoria Perornata. Applied and Environmental Microbiology 69:5319-27. doi:10.1128/AEM.69.9.5319-5327.2003.

Schrader, K. K., and S. T. Summerfelt. 2010. Distribution of off-flavor compounds and isolation of geosmin-producing bacteria in a series of water recirculating systems for rainbow trout culture. North American Journal of Aquaculture 72:1-9. doi:10.1577/A09009.1 . 
Schveitzer, R., R. Arantes, P. F. S. Costodio, C. M. Do Espirito Santo, L. V. Arana, W. Q. Seiffert, and E. R. Andreatta. 2013. Effect of different biofloc levels on microbial activity, water quality and performance of Litopenaeus vannamei in a tank system operated with no water exchange. Aquacultural Engineering 56:59-70. doi:10.1016/j.aquaeng.2013.04.006.

Sokal, R. R., and F. J. Rohlf. 1995. Biometry: The principles and practice of statistics in biological research. Third ed. New York: W. H. Freeman and Company.

Tchobanoglous, G., F. L. Burton, and H. D. Stensel. 2003. Wastewater engineering, treatment and reuse, metcalf \& eddy inc. 4th ed. New York: McGraw-Hill.

Tucker, C. S. 2000. Off-flavor problems in aquaculture. Reviews in Fisheries Science 8:45-88. doi:10.1080/10641260091129170.

United States Environmental Protection Agency (US EPA). 1993. Manual - Nitrogen Control. Washington, DC. Publication EPA/625/R-93/010, Office of Water, US Environmental Protection Agency.

Vinatea, L., A. O. Galvez, C. L. Browdy, A. Stokes, J. Venero, J. Haveman, B. L. Lewis, A. Lawson, A. Shuler, and J. W. Leffler. 2010. Photosynthesis, water respiration and growth performance of Litopenaeus vannamei in a super-intensive raceway culture with zero water exchange: Interaction of water quality variables. Aquacultural Engineering 42:17-24. doi:10.1016/j.aquaeng.2009.09.001.

Water Environment Federation. 1996. Operation of municipal wastewater treatment plants manual of practice No. 11. Fifth ed. Alexandria: Water Environment Federation.

Wiese, N., C. Engle, J. Trimpey, K. Quagrainie, and B. Green. 2006. Reducing catfish farm losses due to dockages assessed by processing plants. Journal of the World Aquaculture Society 37:60-73. doi:10.1111/jwas.2006.37.issue-1. 